\title{
Profil Kemampuan Literasi Sains Siswa SMP Islam As-Shofa Kota Pekanbaru Berdasarkan PISA
}

\author{
M. Syahrum Sujudi ${ }^{1}$, Tengku Idris ${ }^{2}$, Suryanti ${ }^{3}$, Peny Husna Handayani ${ }^{4}$ \\ 1,2,3 Program Studi Pendidikan Biologi, Universitas Islam Riau \\ ${ }^{4}$ Program Studi PG PAUD, Universitas Negeri Medan \\ e-mail: \\ ${ }^{1}$ m.syahrumsujudi@student.uir.ac.id \\ 2idrisbio@edu.uir.ac.id \\ 3suryantibio@edu.uir.ac.id \\ ${ }^{4}$ peny@unimed.ac.id
}

\begin{abstract}
.
This study aims to obtain a description of the scientific literacy skills of As-Shofa Pekanbaru Islamic Junior High School students based on The International Student Assessment (PIS A) Program on Biology content. This research is a descriptive study. The instrument used was a matter of scientific literacy based on PIS A 2009. This study was conducted in April 2019. The population in this study was grade IX students of As-Shofa Islamic Junior High School in Pekanbaru with a sampling technique using proportional stratified sampling so that samples were grouped based on high levels of academic ability, medium and low with a sample of 135 students. The results showed the scientific literacy ability of students of SMP as-Shofa Pekanbaru City in the low category with a percentage of $56.86 \%$. The ability to identify low category problems with a percentage of $56.43 \%$, the competence to explain phenomena scientifically is a low category with a percentage of $54.43 \%$ and the competency to use scientific evidence is a low category with a percentage of $59.71 \%$. From the results of this study it can be concluded that the As-Shofa Islamic Junior High School students in Pekanbaru City have low scientific literacy skills.
\end{abstract}

Keyword: profile, scientific literacy, PISA

\begin{abstract}
ABSTRAK.
Penelitian ini bertujuan untuk memperoleh gambaran kemampuan literasi sains siswa SMP Islam As-Shofa Kota Pekanbaru berdasarkan The Programme Internasional Student Assessment (PISA) pada konten Biologi. Penelitian ini adalah penelitian deskriptif. Instrumen yang digunakan adalah soal literasi sains berdasarkan PISA 2009. Penelitian ini dilaksanakan bulan April 2019. Populasi dalam penelitian ini yaitu siswa kelas IX SMP Islam As-Shofa Kota Pekanbaru dengan teknik pengambilan sampel dengan mengggunakan propotional strtified sampling sehingga sampel dikelompokan berdasarkan tingkat kemampuan akademik tinggi, sedang dan rendah dengan jumlah sampel sebanyak 135 siswa. Hasil penelitian menunjukan kemampuan literasi sains siswa SMP Islam As-Shofa Kota Pekanbaru berada pada kategori rendah dengan persentase 56,86\%. Kemampuan berdasarkan kompetensi mengidentifikasi masalah berada pada kategori rendah dengan persentase 56,43\%, kompetensi menjelaskan fenomena secara ilmiah termasuk pada kategori rendah dengan persentase $54,43 \%$ dan kompetensi menggunakan bukti ilmiah masuk pada kategori rendah dengan persentase 59,71\%. berdasarkan hasil penelitian ini dapat disimpulkan bahawa siswa SMP Islam As-Shofa Kota Pekanbaru memiliki kemampuan literasi sains rendah.
\end{abstract}

Kata kunci: profil, literasi sains, PISA. 


\section{PENDAHULUAN}

Pada era Globalisasi ini dunia pendidikan menjadi salah satu perhatian utama dunia. Salah satu hal yang di utamakan adalah pendidikan berbasis sains. Pemahaan tentang sains dan teknologi merupakan hal yang penting bagi generasi muda untuk mempersiapkan diri dalam masyarakat moderen (OECD, 2014). Ilmu Pengetahuan Alam (IPA) atau sains didefenisikan sebagai pengetahuan yang diperoleh melalui pengumpulan data dan eksperimen, pengamatan, dan dedukasi untuk menghasilkan suatu penjelasan tentang sebuah gejala yang dapat di percaya (Anggraini, 2014).

Biologi merupakan salah satu cabang dari IPA. Hasil belajar yang diperoleh dari pembelajaran di kelas biasanya berupa pengetahuan, sikap dan keterampilan. Agar siswa mengetahui kemampuan apa saja yang belum dicapai secara optimal, maka siswa perlu mendapatkan penilaian hasil belajar untuk menentukan posisi relative siswa terhadap standar yang telah ditentukan. Berdasarkan Permendikbud No.23 tahun 2016 bahwa standar penilaian pendidikan adalah kriteria mengenai ruang lingkup, tujuan, manfaat, prinsip, mekanisme, prosedur, dan instrument penilaian hasil belajar peserta didik yang digunakan sebagai dasar dalam penilaian hasil belajar peserta didik. Pada kurikulum 2013 revisi 2017, ada tiga hal yang harus dicapai kurikulum diantaranya; Karakter, Kompetensi dan Literasi, dari ketiga hal tersebut salah satu pencapaian literasi dan bagaimana penerapan keterampilan inti salah satu pencapaian literasi sains (Harosid, 2017).

Kemampuan literasi sains dapat ditingkatkan dengan memberikan evaluasi terhadap pembelajaran karena literasi sains merupakan kemampuan kunci pada pendidikan anak usia 15 tahun (Zuriyani, 2013). Evaluasi terhadap literasi sains digunakan untuk merumuskan kebijakan yang dapat mendukung terciptanya sumber daya alam yang kompetitif di era globalisasi, hal ini dibuktikan pada (OECD, 2004) bahwa literasi sains sangat diperlukan pada masyarakat modern. Salah satu Evaluasi literasi sains berskala Internasional adalah Programme For International Student Assessment (PISA) yang dilakukan oleh Organization For Economic Cooperation and Development (OECD) yang dilaksanakan mulai tahun 2000 (Sellar, 2014).

Banyak faktor yang mempengaruhi rendahnya literasi sains di Indonesia yaitu gender, ekonomi dan social serta imigrasi (OECD, 2007). Penelitian Anjasari (2014) mengungkapkan bahwa penyebab rendahnya penguasan literasi sains yaitu guru kurang membiasakan proses pembelajaran yang mendukung siswa untuk mengembangkan literasi sains. Berdasarkan hasil observasi di proses pembelajaran terlihat peran guru kurang mendukung perkembangan kemampuan literasi sains siswa.

Peneliti tertarik dengan pemilihan sekolah yang dijadikan penelitian yaitu di sekolah swasta yang memiliki akreditasi A. menurut hasil dari Analytical Capacity Development Program (ACDP) Indonesia tahun 2015, prestasi sains antara murid di Sekolah Negeri dan Swasta memiliki perbedaan yang cukup besar. Murid di Sekolah Negeri mencatat nilai prestasi sains 16 poin lebih tinggi dari Sekolah Swasta. Hasil pengamatan di sekolah menunjukkan bahwa pembelajaran di sekolah SMP Islam As-Shofa sudah bervariasi dan arah pemahaman tentang literasi sains masih kurang diaplikasikan, serta guru di sekolah belum pernah memberikan soal literasi sains yang berdasarkan PISA pada konten Biologi, sehingga kurang membangun aspek literasi sains siswa.

\section{METODOLOGI}

Penelitian ini merupakan penelitian deskriptif dengan menggunakan populasi siswa kelas IX SMP As-Sofa dengan sampel sebanyak 146 orang siswa dengan kategori tinggi, sedang dan rendah. Instrument yang digunakan dalam penelitian ini adalah soal PISA 2009 yang telah diterjemahkan dan divalidasi oleh ahli evaluasi. Soal yang digunakan disesuaikan dengan. yang telah dipelajari di tingkat SMP. Pengelompokkan aspek kompetensi pada soal literasi sains telah 
ditetapkan langsung oleh soal PISA 2009. Skor untuk setiap soal sudah ditetapkan oleh PISA dan juga di analisis kembali oleh peneliti. Tiga Aspek kompetensi ilmiah yang diukur dalam literasi sains dilihat pada Tabel 1

Tabel 1. Sebaran soal literasi sains

\begin{tabular}{|c|c|c|c|}
\hline Aspek kompetensi ilmiah & Indikator & $\begin{array}{l}\text { Topik soal } \\
\text { PISA }\end{array}$ & No. Soal \\
\hline \multirow{3}{*}{$\begin{array}{c}\text { Mengidentifikasi masalah } \\
\text { ilmiah }\end{array}$} & $\begin{array}{l}\text { Mengenali masalah yang mungkin } \\
\text { untuk menyelidiki secara ilmiah. }\end{array}$ & \multirow{3}{*}{$\begin{array}{l}\text { Acid rain } \\
\text { Tooth decay } \\
\text { Tobacco smoking } \\
\text { Evolution } \\
\text { Cloning }\end{array}$} & \multirow{3}{*}{$\begin{array}{l}3,4,5,11,14,15 \\
, 22,19\end{array}$} \\
\hline & $\begin{array}{l}\text { Mengidentifikasi kata-kata kunci } \\
\text { untuk mencari informasi illmiah. }\end{array}$ & & \\
\hline & $\begin{array}{l}\text { Mengenal fitur-fitur utama dari } \\
\text { penyelidikan ilmiah. }\end{array}$ & & \\
\hline \multirow[b]{2}{*}{$\begin{array}{l}\text { Menjelaskan fenomena } \\
\text { secara ilmiah }\end{array}$} & $\begin{array}{l}\text { Menerapkan pengetahuan ilmiah } \\
\text { sains dalam situasi tertentu. }\end{array}$ & \multirow[b]{2}{*}{$\begin{array}{c}\text { Biodiversity } \\
\text { Ozon } \\
\text { Tobacco smoking } \\
\text { Evolution } \\
\text { Cloning } \\
\text { Major surgery }\end{array}$} & \multirow[b]{2}{*}{$\begin{array}{l}1,2,8,12,13,18 \\
, 20,21,23,24\end{array}$} \\
\hline & $\begin{array}{c}\text { Menjelaskan fenomena secara } \\
\text { ilmiah dan memprediksi } \\
\text { perubahan. } \\
\text { Mengidentifikasi deskripsi, } \\
\text { penjelasan dan prediksi yang tepat. }\end{array}$ & & \\
\hline \multirow[t]{2}{*}{ Menggunakan bukti ilmiah } & $\begin{array}{l}\text { Menafsirkan bukti ilmiah, } \\
\text { membuat dan } \\
\text { mengkomunikasikan kesimpulan. }\end{array}$ & \multirow{2}{*}{$\begin{array}{l}\text { ozon } \\
\text { Tooth decay } \\
\text { Evolution } \\
\text { Major surgery }\end{array}$} & \multirow{2}{*}{$\begin{array}{c}6,7,9,10,16,17 \\
, 25\end{array}$} \\
\hline & $\begin{array}{l}\text { Mengidentifikasi asumsi, bukti, } \\
\text { dan alasan dibalik kesimpulan. }\end{array}$ & & \\
\hline & $\begin{array}{c}\text { Mencerminkan implikasi sosial } \\
\text { dari sains dan teknologi } \\
\text { pengembangan. }\end{array}$ & & \\
\hline
\end{tabular}

Soal tes terdiri dari 4 Soal essay, 12 objektif, 2 soal isian singkat, 7 soal piihan ganda. Sehingga total ini berjumlah 25 soal dengan waktu 90 menit. Soal yang berjumlah 25 soal tersebut terbagi atas 3 kategori aspek kompetensi yang digunakan soal tes PISA yaitu; mengidentifikasi permasalahan (20\%), menjelaskan fenomena Ilmiah $(60 \%)$ dan menggunakan bukti ilmiah $(20 \%)$. Hasil penelitian diolah secara deskriptif dengan menggunakan rumus persentase, setelah itu hasil persentase ditabulasi dengan menggunakan aturan Purwanto (2016).

$$
\mathrm{P}=\frac{F}{N} X 100 \%
$$

$$
\begin{array}{ll}
\text { Keterangan } & \text { P: Persentase } \\
& \text { F: Frekuensi } \\
& \text { N : Jumlah Populasi }
\end{array}
$$

Tabel 2. Kategori literasi sains

\begin{tabular}{cc}
\hline Persentase $\%$ & Kategori \\
\hline $81-100$ & Sangat Tinggi \\
\hline $61-80$ & Tinggi \\
\hline $41-60$ & Rendah \\
\hline$\leq 40$ & Sangat Rendah \\
\hline
\end{tabular}




\section{TEMUAN DAN PEMBAHASAN}

Sebelum melaksanakan penelitian ke SMP Islam As-Shofa Kota Pekanbaru, Persiapan pertama yang di lakukan peneliti yaitu mempersipakan seluruh alat pengumpul data yaitu soal tes literasi sains berdasarkan Programme for International Student Assessmet (PISA). Instrumen penelitian di peroleh dari soal literasi sains PISA yang dikelompokkan dan dianalisis berdasarkan kompetensi dasar dari kelas VII, VIII dan IX kurikulum 2013 revisi. Soal literasi sains PISA 2009 yang berjumlah 34 topik, lalu dipilih 8 topik yang sesuai dengan konten biologi dan kompetensi dasar, dari 8 topik dianalisis 25 butir soal yang digunakan pada instrumen penelitian yang terdiri dari soal objektif, essay, isian singkat dan pilihan jamak.

Soal Literasi Sains berdasarkan The Programe for International Student Assessment (PISA) pada konten Biologi, mengacu pada salah satu dimensi literasi sains yaitu Aspek kompetensi. Pada Aspek Kompetensi terdiri dari tiga kompetensi ilmiah yaitu mengidentifikasi masalah ilmiah, menjelaskan fenomena secara ilmiah dan menggunakan bukti ilmiah. Soal literasi sains berdasarkan PISA pada konten biologi terdiri dari 25 soal, terdiri dari 4 Soal essay, 12 objektif, 2 isian singkat dan 7 pilihan jamak.

\section{Kemampuan literasi sains siswa pada kompetensi mengidentifikasi masalah}

Pada Indikator Kompetensi Mengidentifikasi masalah ilmiah yaitu mengenali masalah yang mungkin untuk penyelidikan ilmiah, mengidentifikasi kata kunci untuk mencari informasi ilmiah dan mengenali fitur kunci dari penyelidikan ilmiah (PISA, 2006). Soal mengidentifikasi masalah berjumlah 8 soal yang berada pada nomor 3, 4, 5, 11, 14, 15, 19 dan 22. Guna untuk menafsirkan skor nilai yang diperoleh melalui perhitungan tes, maka untuk mendapatkan presentasinya disesuaikan dengan kriteria yang disajikan oleh Tabel 3.

Tabel 3. Persentase soal kompetensi mengidentifikasi masalah ilmiah

\begin{tabular}{|c|c|c|c|c|}
\hline Kompetensi ilmiah & No. soal & Skor & \% Skor & Kategori soal \\
\hline \multirow{8}{*}{ Mengidentifikasi masalah } & 3 & 103 & $76,29 \%$ & Tinggi \\
\hline & 4 & 85 & $62,96 \%$ & Tinggi \\
\hline & 5 & 44,5 & $32,96 \%$ & S. Rendah \\
\hline & 11 & 67,5 & $50 \%$ & S. Rendah \\
\hline & 14 & 41 & $30,37 \%$ & S. Rendah \\
\hline & 15 & 69,5 & $51,48 \%$ & S. Rendah \\
\hline & 19 & 131 & $97,03 \%$ & S. Tinggi \\
\hline & 22 & 68 & $51,48 \%$ & Rendah \\
\hline \multicolumn{2}{|c|}{ Jumlah } & 609,5 & $451,46 \%$ & \\
\hline \multicolumn{3}{|c|}{ Kategori } & \multicolumn{2}{|c|}{ Rendah } \\
\hline
\end{tabular}

Berdasarkan Tabel 3 dijelaskan bahwa kemampuan literasi sains siswa berdasarkan kompetensi mengidentifikasi masalah ilmiah yang terdiri dari 8 soal, memperoleh skor 609,5 dengan persentase 56,43\% kategori rendah. Dari 8 soal berdasarkan kompetensi mengidntifikasi masalah, kategori soal sangat tinggi pada soal nomor 19, kategori soal tinggi pada soal nomor 3 dan 4 , kategori soal rendah pada soal nomor 22 , kategori soal sangat rendah itu pada nomor soal 5 , 11,14 , dan 15 .

Pada soal dengan kategori sangat tinggi pada soal nomor 19 dengan persentase 97,03\% Siswa memperoleh skor 131. Soal dengan kategori tinggi pada soal nomor 3 dan 4 dengan persentase $76,29 \%$ dan 62,96\% siswa memperoleh skor 103 dan 85. Soal dengan kategori rendah pada soal nomor 22 dengan persentase $51,48 \%$ siswa memperoleh skor 68 . Soal dengan kategori sangat rendah pada soal nomor 5, 11, 14, dan 15 dengan persentase 32,96\%, 50\%, 30,37\% dan $51,48 \%$ siswa memperoleh skor 44,5, 67,5, 41 dan 69,5. Terjadi perbandingan diantara persentase skor soal yang kategori sangat tinggi, tinggi, cukup, dan sangat rendah. 


\section{Kemampuan literasi sains siswa pada kompetensi menjelaskan fenomena secara ilmiah}

Pada indikator kompetensi menjelaskan fmomena secara ilmiah yaitu menerapkan ilmu pengetahuan dalam situasi tertentu, menggambarkan atau menafsirkan fenomena ilmiah dan memprediksi perubahan, mengidentifikasi deskripsi yang, memberi penjelasan dan prediksi yang tepat (PISA, 2006). Soal mengidentifikasi masalah berjumlah 10 soal yang berada pada nomor 1, 2, $8,12,13,18,20,21,23$ dan 24. Guna untuk menafsirkan skor nilai yang diperoleh melalui perhitungan tes, maka untuk mendapatkan presentasenya disesuaikan dengan kriteria yang disajikan oleh Tabel 4.

Tabel 4. Persentase soal kompetensi menjelaskan fenomena secara ilmiah.

\begin{tabular}{|c|c|c|c|c|}
\hline Kompetensi ilmiah & No. soal & Skor & $\%$ Skor & Kategori Soal \\
\hline \multirow{10}{*}{ Menjelaskan masalah secara ilmiah } & 1 & 105 & $77,77 \%$ & Tinggi \\
\hline & 2 & 106 & $78,51 \%$ & Tinggi \\
\hline & 8 & 58 & $42,96 \%$ & S. Rendah \\
\hline & 12 & 29 & $21,48 \%$ & S. Rendah \\
\hline & 13 & 105,5 & $78,14 \%$ & Tinggi \\
\hline & 18 & 62 & $45,92 \%$ & Rendah \\
\hline & 20 & 51 & $37,77 \%$ & S. Rendah \\
\hline & 21 & 58 & $42,96 \%$ & Rendah \\
\hline & 23 & 84,5 & $63,59 \%$ & Tinggi \\
\hline & 24 & 76 & $56,29 \%$ & Rendah \\
\hline \multicolumn{2}{|l|}{ Jumlah } & 735 & $544,39 \%$ & \\
\hline \multicolumn{2}{|l|}{ Kategori } & & & \\
\hline
\end{tabular}

Berdasarkan Tabel 4 dijelaskan bahwa kemampuan literasi sains siswa berdasarkan kompetensi menjelaskan fenomena secara ilmiah yang terdiri dari 10 soal, memperoleh skor 735 dengan persentase 54,43\% kategori rendah. Dari 10 soal berdasarkan kompetensi menjelaskan fenomena secara ilmiah, kategori soal tinggi pada soal nomor 1, 2 dan 13, kategori soal rendah pada soal nomor 18, 21 dan 24, dan kategori soal sangat rendah pada nomor soal 8, 12 dan 20.

Pada soal dengan kategori tinggi pada soal nomor 1, 2 dan 13 dengan persentase 77,77\%, $78,51 \%$ dan 78,14\% Siswa memperoleh skor 105, 106 dan 105,5. Soal dengan kategori rendah pada soal nomor 18, 21 dan 24 dengan persentase 45,92\%, 42,96\% dan 56,29\% siswa memperoleh skor 62, 58 dan 76. Soal dengan kategori sangat rendah pada soal nomor 8, 12, dan 20 dengan persentase 42,96\%, 21,48\% dan 37,77\% siswa memperoleh skor 58, 29 dan 51. Terjadi perbandingan diantara persentase skor soal yang kategori tinggi, rendah dan sangat rendah.

\section{Kemampuan literasi sains siswa pada kompetensi menggunakan bukti ilmiah}

Pada indikator kompetensi menggunakan bukti ilmiah yaitu menafsirkan bukti ilmiah, membuat dan mengkomunikasikan keimpulan, mengidentifikasi asumsi, bukti dan alasan di balik kesimpulan dan mencerminkan implikasi sosial dari saina dan teknologi pembangunan (PISA, 2006). Soal mengidentifikasi masalah berjumlah 7 soal yang berada pada nomor $6,7,9,10,16,17$, dan 25. Guna untuk menafsirkan skor nilai yang diperoleh melalui perhitungan tes, maka untuk mendapatkan presentasinya disesuaikan dengan kriteria yang disajikan oleh Tabel 5. 
Tabel 5. Persentase soal kompetensi Menggunakan Bukti ilmiah.

\begin{tabular}{ccccc}
\hline Kompetensi ilmiah & No. soal & Skor & \% Skor & Kategori Soal \\
\hline \multirow{3}{*}{ Menggunakan Bukti ilmiah } & 6 & 93,5 & $69,25 \%$ & Tinggi \\
\cline { 2 - 5 } & 7 & 53 & $39,25 \%$ & S. Rendah \\
\cline { 2 - 5 } & 9 & 93 & $68,88 \%$ & Tinggi \\
\cline { 2 - 5 } & 10 & 97,5 & $72,22 \%$ & Tinggi \\
\cline { 2 - 5 } & 16 & 55 & $40,74 \%$ & S. Rendah \\
\cline { 2 - 5 } & 17 & 67 & $49,62 \%$ & Rendah \\
\cline { 2 - 5 } & 25 & 105,5 & $78,14 \%$ & Tinggi \\
\hline Jumlah & & 564,5 & $417,73 \%$ & \\
\hline
\end{tabular}

Berdasarkan Tabel 5 dijelaskan bahwa kemampuan Literasi Sains Siswa berdasarkan kompetensi menggunakan bukti ilmiah yang terdiri dari 7 soal, memperoleh skor 564,5 dengan persentase 59,67\% dengan kategori rendah. Dari 7 soal berdasarkan kompetensi menggunakan bukti ilmiah, kategori soal tinggi pada soal nomor 6, 9, 10 dan 25, kategori soal rendah pada soal nomor 17, kategori soal sangat rendah pada soal nomor 7 dan 16.

Pada soal dengan kategori tinggi pada soal nomor 6, 9, 10 dan 25 dengan persentase $69,25 \%, 68,88 \%, 76,29 \%$ dan 78,14\% Siswa memperoleh skor 93, 5, 93, 97,5 dan 105,5. Soal dengan kategori rendah pada soal nomor 17 dengan persentase 49,62\% siswa memperoleh skor 67. Soal dengan kategori sangat rendah pada soal nomor 7 dan 16 dengan persentase $42,22 \%$, $40,74 \%$ siswa memperoleh skor 39,25\% dan 40,74\% dengan jumlah skor 53 dan 55 . Terjadi perbandingan diantara persentase skor soal yang kategori tinggi, rendah, dan sangat rendah.

\section{Kemampuan literasi sains secara umum}

Soal Literasi Sains berdasarkan The Programe for International Student Assessment (PISA) pada konten Biologi, mengacu pada salah satu dimensi literasi sains yaitu Aspek kompetensi. Pada Aspek Kompetensi terdiri dari tiga kompetensi ilmiah yaitu mengidentifikasi masalah ilmiah, menjelaskan fenomena secara ilmiah dan menggunakan bukti ilmiah. Soal literasi sains berdasarkan PISA pada konten biologi terdiri dari 25 soal, terdiri dari 4 Soal essay, 12 objektif, 2 isian singkat dan 7 pilihan jamak. Deskriptif kemampuan lietrasi sains secara umum disajikan Tabel 6.

Tabel 6. Deskripsi kemampuan literasi sains seluruh kompetensi.

\begin{tabular}{cccc}
\hline No. & Kompetensi literasi sains & persentase & Kategori \\
\hline 1. & Mengidentifikasi masalah ilmiah & $56,43 \%$ & Rendah \\
\hline 2. & Menjelaskan fenomena secara ilmiah & $55,43 \%$ & Rendah \\
\hline 3. & Menggunakan bukti ilmiah & $59,67 \%$ & Rendah \\
\hline & Jumlah & $56,86 \%$ & Rendah \\
\hline
\end{tabular}

Berdasarkan Tabel 6 dapat dijelaskan bahwa kemampuan literasi siswa berdasarkan kompetensi mengidentifikasi masalah ilmiah yaitu 56,43\% dengan kategori rendah, menjelaskan fenomena ilmiah yaitu 55,43\% dengan kategori rendah dan menggunakan bukti ilmiah 59,67\% dengan kategori rendah, dan jumlah persentase keseluruhannya yaitu 56,86\% dengan kategori rendah.

\section{Deskriptif kemampuan literasi sains}

Soal Literasi Sains berdasarkan The Programe for International Student Assessment (PISA) pada konten Biologi, mengacu pada salah satu dimensi literasi sains yaitu Aspek kompetensi. Pada Aspek Kompetensi terdiri dari tiga kompetensi ilmiah yaitu mengidentifikasi masalah ilmiah, menjelaskan fenomena secara ilmiah dan menggunakan bukti ilmiah. Soal literasi sains berdasarkan 
PISA pada konten biologi terdiri dari 25 soal, terdiri dari 4 Soal essay, 12 objektif, 2 isian singkat dan 7 pilihan jamak

Untuk melihat perbandingan persentase dari masing-masing soal dengan kompetensi menggunakan bukti ilmiah dapat dilihat pada Gambar 1:

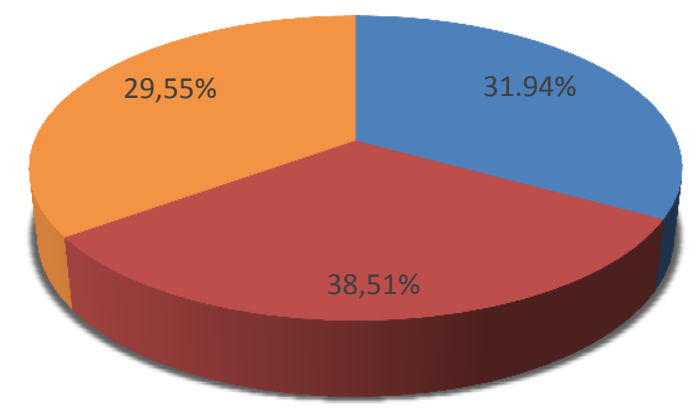

— Mengidentifikasi masalah ilmiah $\mathbf{m}$ menjelaskan fenomena ilmiah menggunakan bukti ilmiah

Gambar 1. Diagram lingkaran perbandingan kemampuan literasi sains berdasarkan PISA pada konten iologi SMP Islam As-Shofa Kota Pekanbaru

Berdasarkan Gambar 1 dapat dijelaskan bahwa kemampuan literasi siswa berdasarkan diagram lingkaran pada mengidentifikai masalah ilmiah yaitu 31,94\%, menjelaskan fenomena ilmiah yaitu 38,51\% dan menggunakan bukti ilmiah 29,55\%.

\section{Kemampuan literasi sains berdasarkan pengelompokan tingkat akademik}

Soal Literasi Sains berdasarkan The Programe for International Student Assessment (PISA) pada konten Biologi, mengacu pada salah satu dimensi literasi sains yaitu Aspek kompetensi. Pada Aspek Kompetensi terdiri dari tiga kompetensi ilmiah yaitu mengidentifikasi masalah ilmiah, menjelaskan fenomena secara ilmiah dan menggunakan bukti ilmiah. Soal literasi sains berdasarkan PISA pada konten biologi terdiri dari 25 soal, terdiri dari 4 Soal essay, 12 objektif, 2 isian singkat dan 7 pilihan jamak. Deskripsi pengelompokan kemampuan literasi sains bedasarkan tingkat akademik tinggi, sedang dan rendah secara umum yang disajikan Tabel 7.

Tabel 7. Deskripsi kemampuan literasi sains berdasarkan pengelompokan tingkat akademik.

\begin{tabular}{cccc}
\hline No. & Tingkat Akademik & persentase & Kategori \\
\hline 1. & Tinggi & $46,56 \%$ & Rendah \\
\hline 2. & Sedang & $41,19 \%$ & Rendah \\
\hline 3. & Rendah & $38,35 \%$ & Sangat Rendah \\
\hline & Jumlah & $42,03 \%$ & Rendah \\
\hline
\end{tabular}

Berdasarkan Tabel 7 dapat dijelaskan bahwa kemampuan literasi siswa berdasarkan pengelompokan tingkat akademik menunjukkan bahwa siswa dengan tingkat akademik tinggi memperoleh 46,56\% dengan kategori rendah, tingkat akademik sedang 41,19\% dengan kategori rendah dan tingkat akademik rendah yaitu 38,35\% dengan kategori sangat rendah. Persentase secara umum yaitu $42,03 \%$ dengan kategori rendah.

Literasi sains (science literacy) berasal dari gabungan dua kata latin, yaitu literatus, artinya ditandai dengan huruf, melek huruf atau berpendidikan dan scientia, yang artinya memiliki pengetahuan. Menurut DeBoer (1991), orang yang pertama menggunakan istilah literasi sains 
adalah Paul de Hart Hurt dari Standford University. Menurut Hurt, science litercy berarti tindakan memahami sains dan mengaplikasikannya bagi kebutuhan masyarakat (Toharudin, Hendrawati dan Rustaman 2011).

Menurut Programme For International Student Assessment (PISA 2012), Literasi Sains didefenisikan sebagai kapasitas untuk menggunakan pengetehuan ilmiah untuk mengidentifikasi pertanyaan memperoleh pengetahuan baru, menjelaskan fenomena ilmiah dan menarik kesimpulan berbasis bukti tentang isu-isu yang berhubungan dengan sains, pemahaman mereka tentang ciri-ciri karakteristik sains sebagai bentuk pengetahuan dan penyelidikan manusia, kesadaran mereka tentang bagaimana sains dan teknologi membentuk lingkungan material, intelektual, budaya kita dan kesedian mereka untuk terlibat dalam isu-isu yang berkaitan dengan sains serta dengan ide-ide sains, sebagai warga negara yang reflektif (OECD, 2013).

Programme for International Student Assessment (PISA) adalah studi yang dikembangkan oleh beberapa negara maju di Dunia yang tergabung dalam OECD yang berkedudukan di Paris, Perancis (Tjalla, 2010). PISA didirikan tahun 1997 dengan tujuan untuk mengukur hasil sistem pendidikan pada prestasi belajar siswa yang berusia 15 tahun. Assessment ini tidak hanya terfokus pada sejauh mana siswa telah menguasai kurikulum sekolah, tetapi melihat kemampuan siswa untuk menggunakan pengetahuan dan keterampilan yang diperoleh siswa dalam kehidupan seharihari (Toharuddin, Hendrawati, \& Rustaman, 2011).

Teknis penyelenggaraan studi PISA dikordinasikan oleh konsorsium International yang diketuai oleh Australian Council for Educational Research (ACER) yang berkedudukan di Melbourne. Australia. Konsorsium ini terdiri atas lembaga penelitian dan pengujian yang terkemuka di Dunia yaitu The Netherlands National Institute for Educational Measurement (CITO), Belanda; Educational Testing Service (ETS), Amerika Serikat; Westat Amerika Serikat (WAS), National institute for Educational Research (NIER), Jepang (Tjalla, 2008).

Berdasarkan hasil penelitian yang dilakukan di SMP Islam As-Shofa Kota Pekanbaru, menunjukan bahwa kompetensi literasi sains siswa masih dalam kriteria rendah. Hal ini diduga karena ketidaksiapan siswa pada saat pelaksanaan tes mengingat materi soal tersebesar dari semester I kelas I sampai Semester II Kelas IX, siswa hanya terbiasa menjawab soal soal yang bersifat hafalan yang hanya menekankan sisi kognitif. Selain itu, juga pembelajaran di kelas pada siswa SMP Islam As-Shofa Kota Pekanbaru belum sepenuhnya mendorong dan melatih literasi sains siswa. Beberapa model yang dapat meningkatkan kemampuan literasi sains adalah pembelajran dengan menggunakan model inkuiri terbimbing (Fitri, I dan Yuni F., 2019)

Kondisi rendahnya kompetensi literasi sains sekolah Swasta dibandingkan dengan sekolah Negeri juga terjadi dalam penelitian Analitical Capacity Development Program (ACDP) Indonesia tahun 2015 dimana siswa di sekolah Negeri mencatat nilai prestasi sains16 poin lebih tinggi dari sekolah Swasta. Dalam penelitian yang dilakukan oleh (Angraini, 2014) di kota solok, kompetensi literasi sains siswa termasuk dalam kriteria sangat rendah hasil capain skor tertinggi 33 dengan skor maksimal 100 .

Selain itu hasil penelitian serupa juga diungkapkan oleh (Ayuningtyas, 2016) di Kecamatan kemilang di Bandar Lampung kompetensi literasi sains siswa dalam kategori sangat rendah. Dari beberapa penelitian yang dilakukan membuktikan bahwa laporan OECD tentang hasil tes PISA 2015 yang menekankan aspek literasi sains, menyebutkan bahwa Indonesia menempati peringkta 64 dari 70 Negara yang mengikutinya, sehingga dapat diartikan bahwa kompetensi literasi sains siswa masih terbilang rendah.

Berdasarkan hasil penelitian memperkuat bahwa rendahnya kompetensi literasi sains dipengaruhi oleh pemahaman siswa tentang literasi sains masih kurang, hal ini dikarenakan siswa belum mematangkan konsep dari literasi sains tersebut sehingga kurang membangun aspek 
kompetensi literasi tersebut, dan guru juga kurang memberikan pemahaman kepada siswa tentang konsep literasi sains.

Capaian kompetensi literasi sains juga ditinjau dari masing-masing aspek kompetensi ilmiah yaitu mengidentifikasi permasalahan ilmiah, menjelaskan fenomena ilmiah dan menggunakan bukti ilmiah, ketiga aspek tersebut sudah terdistribusi dalam soal tes PISA yang diujikan kepada siswa. Hasil penelitian di SMP Islam As-Shofa Kota Pekanbaru, secara keseluruhan masing-masing aspek tersebut masuk dalam kategori rendah.

Capaian kompetensi literasi sains siswa berdasarkan pengelompokan tingkat akademik secara keseluruhan adalah rendah. Pada siswa yang memiliki tingkat akademik tinggi memiliki ratarata persentase dalam kategori rendah. Pada siswa yang memiliki tingkat akademik sedang memiliki rata-rata persentase dalam kategori rendah dan pada siswa yang memiliki tingkat akademik rendah memiliki rata-rata persentase dalam kategori rendah.

Pada siswa yang memiliki tingkat akademik tinggi memiliki rata-rata persentase dalam kategori rendah. Seharusnya siswa meimliki rata-rata persentase dalam kategori tinggi sedangkan pada data yang peneliti amati, terdapat ketidaksesuaian antara kemampuan literasi siswa yang memiliki tingkat kemampuan akademik tinggi dengan rata-rata persentase kemampuan literasi sains siswa, seharusnya anak kemampuan akademik tinggi memiliki kemampuan literasi sains tinggi. dikarenakan ada beberapa permasalahan yang siswa temui dalam menjawab soal literasi sains berdasarkan PISA pada konten biologi. Lebih jelas dapat dilihat dari hasil wawancara anak yang memiliki tingkat kemampuan akademik tinggi.

Hasil wawancara anak kemampuan akademik tinggi, hasil jawaban soal literasi sains berdasarkan PISA yang telah dijawab oleh siswa berkemampuan akademik tinggi, mengalami beberapa kesulitan pada saat menjawab soal tersebut. Model soal yang sulit yaitu pada soal essay dan yang paling mudah dipahami yaitu pada soal objektif. Dari keseluruhan soal, siswa dengan tingkat kemampuan akademik tinggi berpendapat kategori soal literasi sains berdasarkan PISA itu termasuk kategori sedang.

Pada siswa yang memiliki tingkat akademik sedang memiliki rata-rata persentase dalam kategori rendah. Hal ini dikarenakan ada beberapa permasalahan yang siswa temui dalam menjawab soal literasi sains berdasarkan PISA pada konten biologi. Lebih jelas dapat dilihat dari hasil wawancara anak yang memiliki tingkat kemampuan akademik sedang.

Hasil wawancara anak kemampuan akademik sedang, hasil jawaban soal literasi sains berdasarkan PISA yang telah dijawab oleh siswa kemampuan akademik sedang ditemukan bahwa mereka mengalami beberapa kesulitan pada saat menjawab soal tersebut. model soal yang sulit yaitu pada soal pilihan jamak dan yang paling mudah dipahami yaitu pada soal objektif. Siswa dengan tingkat kemampuan akademik sedang berpendapat kategori soal literasi sains berdasarkan PISA itu termasuk kategori sedang, karena materi pada soal ada sebagaian yang dapat dipahami dan sebagian soal lagi tidak.

Pada siswa yang memiliki tingkat akademik rendah memiliki rata-rata persentase dalam kategori rendah. Ada beberapa permasalahan yang siswa temui dalam menjawab soal literasi sains berdasarkan PISA pada konten biologi. Lebih jelas dapat dilihat dari hasil wawancara anak yang memiliki tingkat kemampuan akademik rendah.

Hasil wawancara dengan siswa yang berkemampuan akademik rendah dilakukan berkaitan dengan hasil jawaban soal literasi sains berdasarkan Programme for International Student Assessment (PISA) yang telah dijawab oleh siswa kemampuan akademik rendah. Mereka mengalami beberapa kesulitan pada saat menjawab soal tersebut. Model soal yang sulit yaitu pada soal objektif dan yang paling mudah dipahami yaitu pada soal essay. Keseluruhan soal siswa dengan tingkat kemampuan akademik rendah berpendapat kategori soal literasi sains berdasarkan PISA itu termasuk kategori sedang. 
Berdasarkan hasil penelitian yang peneliti amati, rendahnya kompetensi literasi sains dipengaruhi oleh pemahaman guru dan siswa yang masih kurang. Penyebabnya adalah guru kurang mematangkan konsep literasi sains, memberikan pemahan tentang literasi sains dan penerapan literasi sains dalam proses pembelajaran. Siswa juga memiliki minat membaca yang kurang, pemahaman tentang literasi sains masih kurang sehingga kurang mendukung dalam pembangunan konsep lietrasi sains dalam proses pembelajaran.

Kondisi rendahnya kompetensi literasi sains sekolah Swasta dibandingkan dengan sekolah Negeri juga terjadi dalam penelitian Analitical Capacity Development Program (ACDP) Indonesia tahun 2015 dimana siswa di sekolah Negeri mencatat nlai prestasi sains16 poin lebih tinggi dari sekolah Swasta. Dalam penelitian yang dilakukan oleh (Angraini, 2014) di kota solok, kompetensi literasi sains siswa termasuk dalam kriteria sangat rendah hasil capain skor tertinggi 33 dengan skor maksimal 100.

Selain itu, hasil penelitian serupa juga diungkapkan oleh (Ayuningtyas, 2016) di Kecamatan kemilang di Bandar Lampung kompetensi literasi sains siswa dalam kategori sangat rendah. Dari beberapa penelitian yang dilakukan membuktikan bahwa laporan OECD tentang hasil tes PISA 2015 yang menekankan aspek literasi sains, menyebutkan bahwa Indonesia mnempati peringkta 64 dari 70 Negara yang mengikutinya, sehingga dapat diartikan bahwa kompetensi literasi sains siswa masih terbilang rendah.

Rendahnya kompetensi ilmiah yang dimiliki oleh siswa menurut (Puspendik, 2011) hal tersebut dikarenakan rendahnya kompetensi profesionalisme guru, latar belakang guru dengan mata pelajaran yang diampu tidak sesuai khususnya untuk guru dengan mata pelajaran yang diampu tidak sesuai khususnya untuk guru IPA SMP masih terdapat guru Biologi yang mengajar Fisika dan kimia atau sebaliknya, dikarenakan adanya pembelajaran IPA terpadu, sehingga tidak bisa mengajar lebih mendalam. Selain itu pelatoihan guru belum efektif serta Musyawarah Guru Mata Pelajaran (MGMP) belum optimal.

\section{SIMPULAN}

Berdasarkan hasil penelitian yang telah dilakukan tentang kemampuan literasi sains siswa dengan menggunakan The Programe for International Student Assessment (PISA) pada konten Biologi, maka dapat disimpulkan bahwa kompetensi literasi sains siswa SMP Islam As-Shofa Kota Pekanbaru berada pada kategori rendah dengan persentase 56,86\%. Kemampuan berdasarkan kompetensi mengidentifiksi masalah berada pada kategori rendah dengan persentase 56,43\%, kompetensi menjelaskan fenomena secara ilmiah berada pada kategori rendah dengan persentase $55,43 \%$ dan kompetensi menggunakan bukti ilmiah berada pada kategori rendah dengan persentase $59,67 \%$.

\section{REFERENSI}

Anggraini, G. (2014). Analisis Kemampuan Literasi Sains Siswa SMA Kelas X Di Kota Solok. Prosiding Mathematic And Science Forum 2014 (online). Tersedia di upgrismg.ac.id/index.php/masif2014/view/427/378. Diakses Pada tanggal 2 November 2018, 09.15WIB.7 hlm.

Anjasari. P. (2014). Literasi Sains dalam Kurikulum dan Pembelajran IPA SMP. Yogyakarta: Universitas Negeri Yogyakarta: Yogyakarta.

Asrukin, M. (2012). Pengindeksan Tuntas Berbasis Kurikulum.page 1-12 (online) Tersedia di www.library.um.ac.id/images/gbpjs/art05ask.pdf. 
Ayuningtyas, R, S. (2016). Profil Kompetensi Literasi Sains Siswa berdasarkan PISA pada Konten Biologi. Skripsi FKIP UNILA: Lampung.

Balitbang. (2011). Survei Internasional PISA. Kemendikbud (Online). Tersedia di http://litbang. kemdikbud.go. id/index.php/survei-internasional-pisa.

Connyta, E. (2016). Profil Kompetensi Literasi Sains Siswa berdasarkan The Programme For Internasional Student Assessment (PISA) Pada Konten Biologi (Kuasi Deskriptif siswa kelas IX SMP Se-Kecamatan Kemiling di Bandar Lampung.

DeBoer, E, G. (1991). A History of Ideas in Science Education. New York: .Teacher College Press.

Fitri, I., Yuni, F. (2019). Penerapan Model Pembelajaran Inkuiri Terbimbing Untuk Mendukung Kemampuan Literasi Sains Sisa pada Materi Sistem Koloid. Journal of Natural Science and Integration, 2(2), 181-190.

Firman, H. (2007). Analisis Literasi Sains Berdasarkan Hasil PISA Nasional Tabun 2006. Jakarta: Pusat Penilaian Pendidikan Balitbang Depdiknas.

Harosid, H. (2017). Kurikulum 2013 Revisi 2017. Tersedia di https://Scribd.com. Diakses pada tanggal 30 Oktober 2018, 09. 30 WIB.59 hlm.

OECED-PISA. (2004). Learning for Tomorrow's World. USA: OECD-PISA.

OECD. PISA. (2007). PISA 2006 Science Competencies For Tomorrow's World. Volume 1. Paris, France: OECD. Diakses pada tanggal 3 November 2018, 08.25WIB. http://www.oecd.org/dataoecd/1/53/38484866.pdf.

OECD.PISA. (2009). PISA 2009 result: Executive Summary (online). Diakses pada tanggal 5 November 2018, 09.33WIB.https://www.oecd.org/newsroom.pdf.

OECD. PISA. (2010). Draft PIS A 2012 Assessment Framework (online). Diakses pada tanggal 6 November 2018, 10.15WIB. https://www.oecd.org/data.pdf.

OECD. PISA. (2012). How your school compares internationally. OECD Publishing (online). Tersedia di www.oecd.org/publishing/corrigenda. Diakses pada tanggal 7 November 2018, 11.35WIB.159hlm.

OECD. PISA. (2014). PISA 2012 result in focus. OECD Publishing (online). Tersedia di https://www.oecd.org/pisa/keyfinding/pisa-2012-result.pdf Diakses pada tanggal 10 November 2018, 08.46WIB.

Poedjiadi, A. (2005). Sains teknologi Masyarakat: Pendekatn Pembelajaran Kontekstual Bermuatan Nilai. Bandung: Remaja Rosdakarya.

PISA. Infographic. (2015). ACDP- Indonesia.org. Diakses pada tanggal 10 November 2018, 10.34WIB. 2 hlm.https://puspendik.kemendikbud.go.id. 
Rahayu. (2014). Menuju Masyarakat berliterasi Sains: Harapan Dan Tantangan Kurikulum 2013 (online). https://kimia.um.ac.id/wpcontent/uploads2014.pdf Diakses pada tanggal 11 November 2018, 09.13WIB.

Sariono. (2014). Kurikulum 2013: Kurikulum Berbasis Emas. E-Jurnal Dinas Pendidikan kota surabaya, 3, page 1-9 (online). Diakses pada tanggal 14 November 2018, 10.24WIB. https://dispendik.surabaya.go.id/jurnal/199.pdf.

Sellar, S dan B. Lingard. (2014). The OECD and The Expansion of PISA: New Global Modes of Governance in Education. Brits Educatin Research Journal, 40 (6), 917-936.

Sugiyono. (2016). Metodologi penelitian kuantitatif, kualitatif, dan R\&D. Alfabeta: Bandung $330 \mathrm{hlm}$.

Permendikbud. (2016). Peraturan mentri pendidikan dan kebudayaan RI Nomor.23 tahun 2016 pasal 1 Ayat 1 tentang Standar Peniaian Pendidikan.

Purwanto, N. (2013). Prinsip-prinsip dan Teknik Evaluasi Pengajaran. Remaja Rosda karya. Bandung. $165 \mathrm{hlm}$.

Puspendik. (2011). Asesmen media informasi dan komunikasi penilaian pendidikan. Kemendikbud.Vol.8.No.3. Tersedia di Litbang.kemendikbud.go.id. Diakses pada tanggal 20 Maret 2019,09.20WIB.43 hlm.

Tjalla, A. (2010). Potret Mutu Pendidikan Indonesia ditinjau dari Hasil-Hasil Studi Internasional. Artikel Temu Ilmiah Nasional Guru II "Membangun Profesionalitas Insan Pendidikan yang Berkarakter dan Berbasis Budaya" 24-25 November, Tangerang Selatan.

Toharudin, U., S. Hendrawati. \& A. Rustaman. (2011). Membangun Literasi Sains Peserta Didik. Humaniora, Bandung. $291 \mathrm{hlm}$.

Tohir, Mohammad. (2016). Hasil PIS A Indonesia Tahun 2015 Mengalami Peningkatan. Diakses pada tanggal 26 November 2018, 08.40WIB. tersedia di https://matematohir.wordpress.com/hasil-pisa-indonesia-tahun-2015.

Zuriyani, (2013). Literasi Sains dan Pendidikan (online) Tersedia di http://sumsel.kemenag.go.id/file/file/TULISAN/WAGJ1343099486.pdf. Diakses pada tanggal 25 Januari 2020. 